\title{
Homology modeling and functional characterization of multidrug effluxor Mta protein from Bacillus Atrophaeus: An explanatory insilico approach
}

\author{
Mohammad Rejaur Rahman ${ }^{1 *}$, Ishtiak Malique Chowdhury², Anik Banik ${ }^{3}$, \\ Emran Hossain Sajib ${ }^{3}$
}

Affiliation:

1. Assistant Professor, Department of Molecular Biology \& Genetic Engineering, Sylhet Agricultural University, Sylhet, Bangladesh.

2. MS student, Department of Molecular Biology \& Genetic Engineering, Sylhet Agricultural University, Sylhet, Bangladesh.

3. Faculty of Biotechnology \& Genetic Engineering, Sylhet Agricultural University, Sylhet, Bangladesh.

20 Corresponding Author Name and address:

Mohammad Rejaur Rahman, Assistant Professor, Department of Molecular Biology and Genetic Engineering, Sylhet Agricultural University, Sylhet-3100, Bangladesh. Mobile: +880167586075

Email: rejaur.mge@sau.ac.bd 


\begin{abstract}
Phenotypically similar to B. subtilis, Bacillus atrophaeus is a Gram-positive, aerobic, sporeforming bacteria. It is a black-pigmented bacterial genus. Therefore, it is of interest to study the uncharacterized proteins in the genome. For a detailed computational sequence-structurefunction analysis using available data and resources, an uncharacterized protein Mta (AKL87074.1) in the genome was selected. In this study, attempts were made to study the physicochemical properties, predict secondary structure, modeling the 3-D protein, pocket identification, protein-protein interaction and phylogenetic analysis of Mta protein. The predicted active site using CASTp is analyzed for understanding their multidrug resistance function. Because Mta is a MerR family member, these investigations on these functional aspects could lead us for better understanding of antibiotic resistance phenomenon.
\end{abstract}

Keywords: Bacillus atrophaeus, Mta protein, MerR family, Homology, Antibiotic Resistance 


\section{Introduction}

The development and use of antibiotics has been one of the most important steps towards controlling infectious diseases in the 20th century. However, the subsequent appearance and spread of antibiotic resistance in pathogenic organisms have made many currently available antibiotics ineffective (Moellering Jr, 1998). So, Bacterial multidrug resistance (MDR) is a growing threat to human and animal health. To successfully fight the increasing numbers of drug resistant and multidrug-resistant (MDR) bacteria, extensive knowledge of the molecular mechanisms underlying microbial antibiotic resistance is required.

Microorganisms have developed various ways to resist the toxic effects of antibiotics and other drugs (Neu, 1992). One of these mechanisms involves the efflux of structurally and chemically diverse compounds, including antibiotics, antiseptics, and disinfectants, by membrane-bound multidrug transporters (Van Veen et al., 1999). The natural function of these proteins lies in protecting bacteria from external toxic chemicals. Indeed, these transporters have been found to provide enteric bacteria with natural resistance to bile salts (Baranova et al., 1999). On the basis of bioenergetic and structural criteria, multidrug transporters can be divided into two major classes. Secondary multidrug transporters utilize the transmembrane electrochemical gradient of protons or sodium ions to drive the extrusion of drugs from the cell. ATP-binding cassette (ABC)-type multidrug transporters use the free energy of ATP hydrolysis to pump drugs out of the cell.

Multiple multidrug transporters have been identified in Bacillus subtilis (Ohki and Murata, 1997; Kim et al., 2009), Escherichia coli (Edgar and Bibi, 1997), Pseudomonas aeruginosa (Kohler et al., 1997), Lactococcus lactis (Lubelski et al., 2006; van Veen et al., 1996), Bacillus atrophaeus UCMB-5137 (Baranova et al., 1999) Staphylococcus aureus (Floyd et al., 2010), Streptococcus pneumonia (Hashimoto et al., 2013; Boncoeur et al., 2012), Mycobacterium fortuitum (Aínsa et al., 1998), Mycobacterium tuberculosis (Aínsa et al., 1998) and Corynebacterium glutamicum (Yang et al., 2014). In Bacillus subtilis, there are two multidrug transporters namely Bmr and Blt, which belong to secondary multidrug transporters class. Mta (multidrug transporter activation), a member of the MerR family of bacterial regulatory proteins, is a global activator of B. subtilis multidrug transporter genes and constitutively activates transcription of Bmr and Blt, 
another putative membrane protein gene (ydfK) and its own gene (Godsey et al., 2001). MerR family members are dimeric proteins (Newberry \& Brennan, 2004) and the majority of regulators in this family are activated in response to stress signals in bacteria, such as oxidative stress, heavy metals, cytotoxic compounds or antibiotics (Brown et al., 2003). So, activation of Mta ptotein activated drug transporters such as Bmr and Blt which successfully efflux the drug compounds out of the cell and exhibit resistance to drugs and antibiotics. To fight against the antibiotic resistance and drug resistance challenges, MerR family of regulatory protein like Mta protein is now a research interest.

In silico analysis of genes and proteins has been receiving greater attention with particular emphasis to find suitable biomarkers for rapid identification of different pathogenic genera (Kumar et al., 2016), designing of drugs to combat the pathogenic microbes and superbugs (Karumuri et al., 2015), diagnosis of infectious diseases (Kalia \& Kumar, 2015), structural and functional analysis of proteins and enzymes (Pramanik et al., 2017), and discovery of potent microbial representative useful for several agricultural and animal feed industries (Vermaet al., 2016; Pramanik et al., 2017 ). In the present study Mta protein of Bacillus atrophaeus UCMB5137 were used for in silico analysis. Bacillus atrophaeus UCMB-5137 is an aerobic, grampositive, endospore-forming, rod-shaped bacterium whose description is nearly just like that of Bacillus subtilis except for the production of a pigment on media containing an organic source of nitrogen. (Nakamura, L. K.1989). Attempts were made to study the physicochemical properties, predict secondary structure, modeling the 3-D protein, pocket identification, protein-protein interaction and phylogenetic analysis of Mta protein. 


\section{Materials and Methods}

\section{Recovery of the Targeted Sequence}

The NCBI database (http://www.ncbi.nlm.nih.gov/) gives access to Biomedical and genomic data of numerous living beings. This database was utilized for the recovery of FASTA sequence of Mta protein. The FASTA format of the sequence was used for further in silico analysis.

\section{Analysis of Physico-Chemical Properties}

Physico-chemical properties of the targeted protein sequence was analyzed by the ProtParam (http://web.expasy.org/protparam/) (Gasteiger, 2005) tool of ExPASy server. Utilizing this tool we analyzed molecular weight, theoretical pI, aliphatic index (AI), instability index, extinction co-efficients, GRAVY (grand average of hydropathy), amino acid composition, atomic composition etc.

\section{Secondary Structure Prediction}

The secondary structures combine to form the tertiary (3D) structure that determines the function of a protein. PSIPRED v3.3 (http://bioinf.cs.ucl.ac.uk/psipred/) (Liam J. McGuffin, 2000) and CFSSP: Chou and Fasman Secondary Structure Prediction server (http://chofas.sourceforge.net/) (Kumar, 2003) were used to predict the overall secondary structure of Mta protein and to count the number of helices, sheets and turns.

\section{Homology Modeling, Refinement and Model Quality Assessment}

The I-TASER server (Yang et al., 2015) was utilized for determining the 3D structure of Mta protein based on the degree of similarity between the target protein and available template structure from PDB. Refinement was performed using GalaxyWEB server (http://galaxy.seoklab.org/) (Ko et al., 2012). The refined protein structure was validated through the Ramachandran plot assessment by the RAMPAGE software (http://mordred.bioc.cam.ac.uk/ rapper/rampage.php) (Lovell et al., 2003) and the quality factor was assessed by using ERRAT server (https://servicesn.mbi.ucla.edu/ERRAT/) (Colovos \& Yeates, 1993). 


\section{Sub-cellular Localization and active site determination}

Sub-cellular localization determination is crucial for understanding protein function and is also vital for genome analysis. Sub-cellular localization of the Mta was determined by CELLO version 2.5 (Yu et al., 2004) which is a multiclass support vector machine classification system. Another two servers ngLOC (King \& Guda, 2007) and PSIpred (Buchan \& Jones, 2019) were also used for confined conformation. The generated 3D model was further used for finding pocket to identify residues which are involved in binding of substrate or transcription factor. Active site of the protein was determined by the computed atlas of surface topography of proteins (CASTp) server (Tian, 2018).

\section{Functional Analysis}

The Mta protein was analyzed for the presence of conserved domains based on sequence similarity search with near orthologous family individuals. For this purpose, NCBI database (http://www.ncbi.nlm.nih.gov/cdd/) was used (Marchler-Bauer, 2014). To identify the super family and family of the Mta protein, SUPERFAMILY 2.0 server (http://supfam.org/) was used (Gough, 2001). In order to find the motif present in Mta protein Motif Search tool (https://www.genome.jp/tools/motif/) was used (Kanehisa, 2002). Protein-protein interaction (PPI) plays an amazingly momentous part within the development, propagation, and digestion system of all lives. To know the interaction of Mta protein of Bacillus atrophaeus UCMB-5137 with other closely related proteins STRING v11 (http://string-db.org/) server (Szklarczyk, 2018) was used.

\section{Phylogenetic Analysis}

Phylogenetic analysis is vital since it improves our understanding of how genes, genomes, species (and molecular sequences more generally) evolve. The UPGMA tree was constructed for focused on protein utilizing MEGA software (Kumar, 2018). 


\section{Result}

\section{Sequence retrieval}

An Mta protein from the species Bacillus atrophaeus UCMB-5137 with accession number AKL87074.1 has been retrieved from NCBI database that comprise of 244 amino acids for this computational study.

\section{Analysis of physico-chemical properties}

Physiochemical characterization is very crucial to characterize a specific protein. Table 1 shows the different physiochemical properties of Mta protein of Bacillus atrophaeus UCMB-5137. Isoelectric point $(\mathrm{pI})$ is the $\mathrm{pH}$ at which the surface of protein is covered with charge but net charge of protein is zero. Isoelectric point (pI) of Mta protein is 5.44. So it seemed acidic protein. Average molecular weight of the protein is $28961.95 \mathrm{Da}$. The instability index (II) of the protein is 44.04 which classifies this protein may be unstable in nature (), but on contrary the protein showed higher aliphatic index (80.70) which suggested that the protein is thermostable. The GRAVY value for this protein is very low (-0.697) and Lower value of GRAVY shows that the proteins have better interaction with water.

\begin{tabular}{|c|c|c|c|c|c|c|c|c|c|}
\hline \multicolumn{10}{|c|}{ AKL87074.1 Mta [Bacillus atrophaeus UCMB-5137] } \\
\hline $\begin{array}{c}\text { Number } \\
\text { of } \\
\text { amino } \\
\text { acids }\end{array}$ & $\begin{array}{c}\text { Molecular } \\
\text { weight }\end{array}$ & $\begin{array}{l}\text { Theoretical } \\
\text { pI }\end{array}$ & $\begin{array}{c}\text { Total number } \\
\text { of negatively } \\
\text { charged } \\
\text { residues (Asp } \\
\text { + Glu) }\end{array}$ & $\begin{array}{c}\text { Total } \\
\text { number of } \\
\text { positively } \\
\text { charged } \\
\text { residues } \\
\text { (Arg + } \\
\text { Lys) }\end{array}$ & $\begin{array}{c}\text { Ext. } \\
\text { coeffici } \\
\text { ent }\end{array}$ & $\begin{array}{c}\text { Estimated } \\
\text { half-life }\end{array}$ & $\begin{array}{l}\text { The } \\
\text { instability } \\
\text { index (II) }\end{array}$ & $\begin{array}{c}\text { Aliphatic } \\
\text { index }\end{array}$ & $\begin{array}{c}\text { Grand } \\
\text { average of } \\
\text { hydropathicity } \\
\text { (GRAVY) }\end{array}$ \\
\hline 244 & 28961.95 & 5.44 & 43 & 33 & 26360 & $\begin{array}{c}>20 \text { hours } \\
\text { (yeast, in } \\
\text { vivo). } \\
>10 \text { hours } \\
\text { (Escheric } \\
\text { hia coli, in } \\
\text { vivo). }\end{array}$ & 44.04 & 80.70 & -0.697 \\
\hline
\end{tabular}


bioRxiv preprint doi: https://doi.org/10.1101/2020.12.29.424731; this version posted December 30, 2020. The copyright holder for this preprint (which was not certified by peer review) is the author/funder, who has granted bioRxiv a license to display the preprint in perpetuity. It is made available under aCC-BY-NC-ND 4.0 International license.

\section{Table 1: Physiochemical analysis}

\section{Secondary Structure Prediction}

\begin{abstract}
10
20

30

40

50

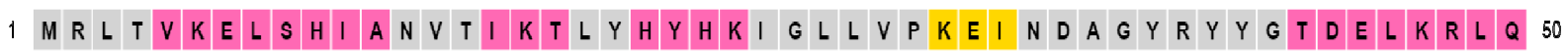

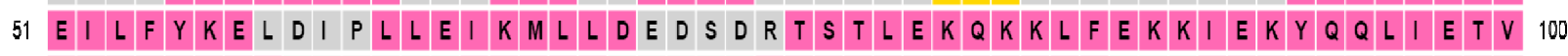

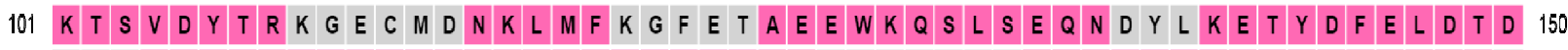

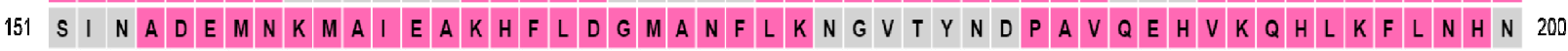
201 G H P I T K K E $D$ D $Y$ V V $Q$ Q $Q$ Q T K K F F

\section{Secondary Structure:}

Query 1 Helix 1 Sheet 1 Turns 1 Struc 1

Query 71 Helix 71 Sheet 71 Turns 71 Struc 71
MRLTVKELSHIANVTIKTLYHYHKIGLLVPKE INDAGYRY

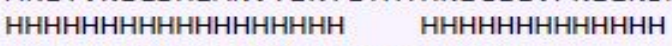
EEEEEEEEEEEEEEEEEEEEEEEEEE $\mathrm{T}$ EEEEE RLQETLFYKELDIPLLEIKMLLD 70 ННННННННННННННННННННННННННН 70 TT

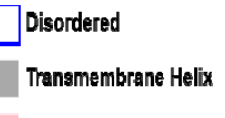

Signal Peptide

Query 141 ETYDFELDTDSINADEMNKMAIEAKHFLDGMANFLKNGVTYNDPAVQEHVKQHLKFLNHNGHPITKEDYV 210

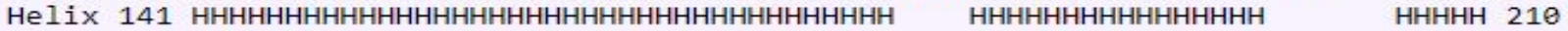

Sheet 141 EEEEEEEEE EEE EEEEEEEEEEEEEE E

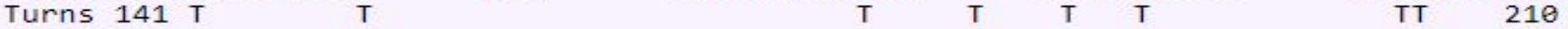

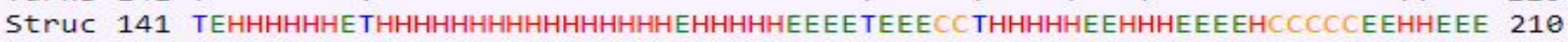

Query 211 QQTKFFMQDDFHRGMLEEQQRGLAYYLVFVSENL 244

Helix 211 ННННННННННННННННННННННННННННННННН 244

Sheet 211 EEEEEEEEEEEEEEEEEEEEEEEEEEEEE

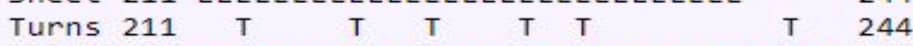

Struc 211 HEEHEHHHTHEHHНHНHHEEHEEEEEEEHHHHHC 244

Total Residues: H: 205 E: $177 \quad$ T: 31

Percent: $\mathrm{H}: 84.0 \quad \mathrm{E}: 72.5 \quad \mathrm{~T}: 12.7$ 

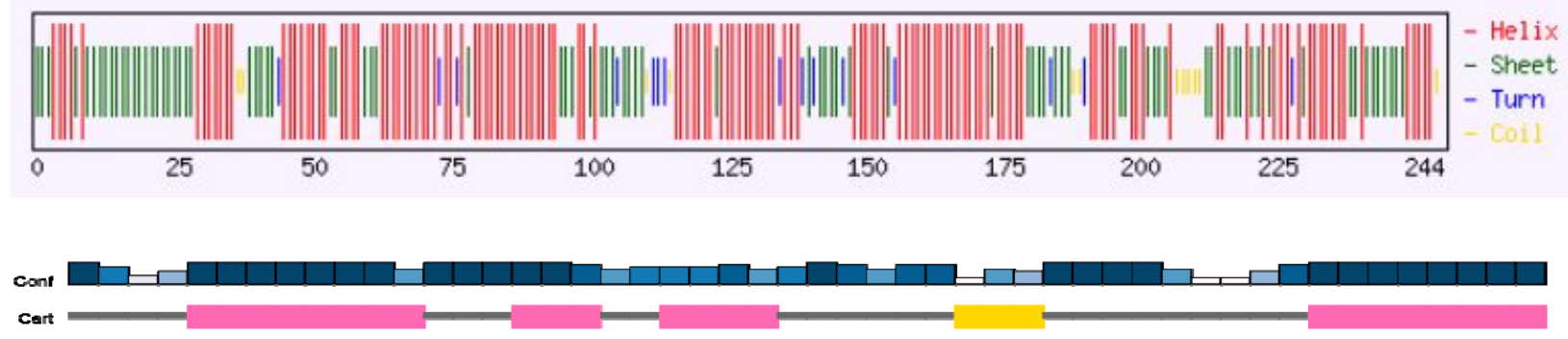

Pred C C C C H H H H H H C C H H C C H H H C C C C CEEECCCCCCC C H H H H H H AA MRLTVKELSHI ANVTI KTLYHYHKI GLLVPKEI NDAGYRYYGTDELKRLQ

10

32

so

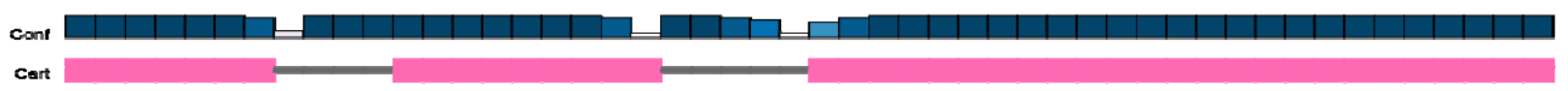

Pred H H H H H C C C CH H H H H H C C C CH H H H H H H H H H H H H H H H H A E I LFYKELDI PLLEI KMLLDEDSDRTSTLEKQKKLFEKKIEKYQQLIETV

eo $7 c$

80

80

100

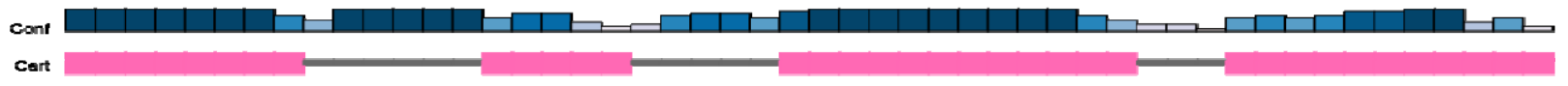

Pred H H H H H H C C C C C H H H C C C C C H H H H H H H H C C CH H H H H H H A KT SVDYTRKGECMDNKL MFKGFETAEEWKQSLSEQNDYLKETYDFELDTD
111
120
130

150

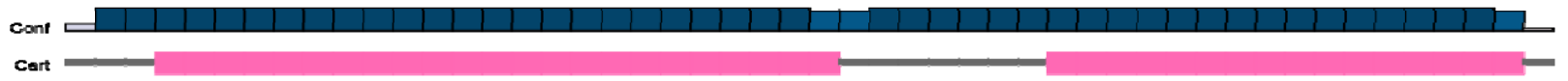

Pred C C C H H H H H H H H H H H H H H H H H H C C C C C C H H H H H H H H H H H C AA SINADEMNKMAIEAKHFLDGMANFLKNGVTYNDPAVOEHVKOHLKFLNHN

160

170

180

$1 \varepsilon 0$

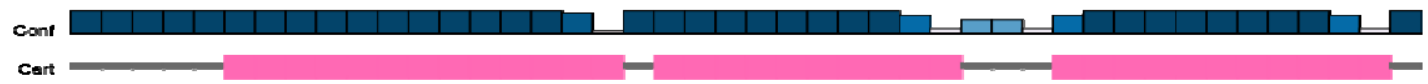

Pred C C C C C H H H H H H H H H H C H H H H H H H H C C H H H H H H H H H C

AA GHPI TKEDYVQQTKFF MQDDFHRGMLEEQQRGLAYYLVFVSENL

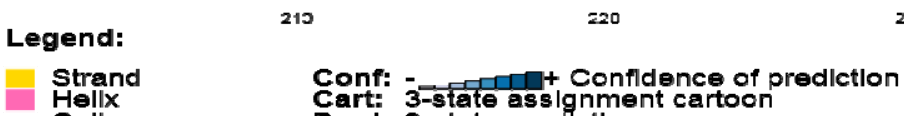

Pred: 3-state predction
AA: Target Sequence

Figure 1. Secondary structure analysis of Mta protein.

The secondary structure is the intuitive that happen between the $\mathrm{C}, \mathrm{O}$, and $\mathrm{NH}$ bunches on amino acids in a polypeptide chain to create $\alpha$-helices, $\beta$-sheets, turns, circles, and other shapes. The percentile contribution of three classes of secondary arrangements viz. Helices, Sheets and Turns are $84 \%, 72.5 \%$ and $12.7 \%$ respectively which is deduced from the web server (Fig. 1). This result indicates that helices $>$ sheets $>$ turns in the protein. Disordered protein binding site was not detected (Fig.1). Secondary arrangements indicates that the Mta protein is folded, which indicates the stable nature of protein. Here, a very higher percentage of $\alpha$-helical conformation indicates that the protein is thermostable (Pramanik et al. 2017). The limitations of X-ray Crystallography and NMR are overcome by the prediction of secondary structure elements of 
protein (Roy et al., 2015). In silico characterization including secondary structure prediction of ACC deaminase protein of Mesorhizobium were done by Pramanik et al. (2017), the phytase of different Bacillus spp. by Verma et al. (2016). Roy et al. (2015) reported that the prediction of secondary structural elements was vital to detect the conformational changes within the protein of interest.

\section{Homology Modeling}

I-TASSER predicted five models for Mta protein of Bacillus atrophaeus UCMB-5137, which were ranked based on cluster size. The LOMETS threading programs selected ten best templates (with the highest Z-score) that were used to predict the tertiary structures. Homology modeling was performed by using 3qaoA from RCSB Protein Data Bank as a best suited template for Mta protein. Results showed that model 1 had the highest C-Score of -3.01 while the estimated TMscore and RMSD were $0.37 \pm 0.13$ and $12.9 \pm 4.2 \AA$ (Fig. 2). After refinement by RAMPAGE, $80.6 \%$ and $14.5 \%$ residues were in the favored and allowed region revealed by Ramachandran plot analysis (Fig. 2). The ERRAT server showed that this predicted model has a quality factor of 62.66. In silico based homology modeling was also shown by several workers [17-19, 31, 33] to predict a variety of $3 \mathrm{D}$ protein models of interest. 
bioRxiv preprint doi: https://doi.org/10.1101/2020.12.29.424731; this version posted December 30, 2020. The copyright holder for this preprint (which was not certified by peer review) is the author/funder, who has granted bioRxiv a license to display the preprint in perpetuity. It is made available under aCC-BY-NC-ND 4.0 International license.
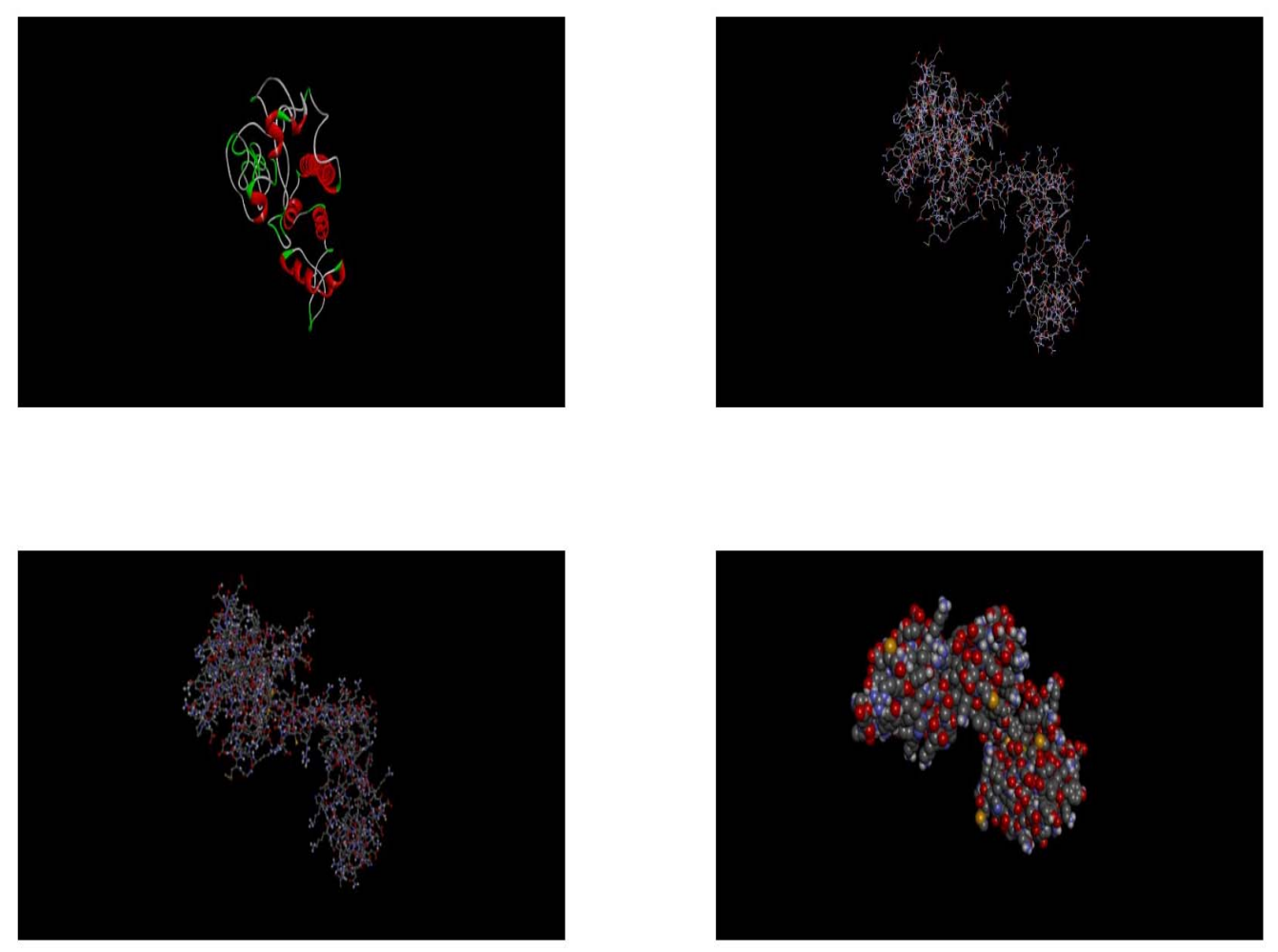
bioRxiv preprint doi: https://doi.org/10.1101/2020.12.29.424731; this version posted December 30, 2020. The copyright holder for this preprint (which was not certified by peer review) is the author/funder, who has granted bioRxiv a license to display the preprint in perpetuity. It is made available under aCC-BY-NC-ND 4.0 International license.
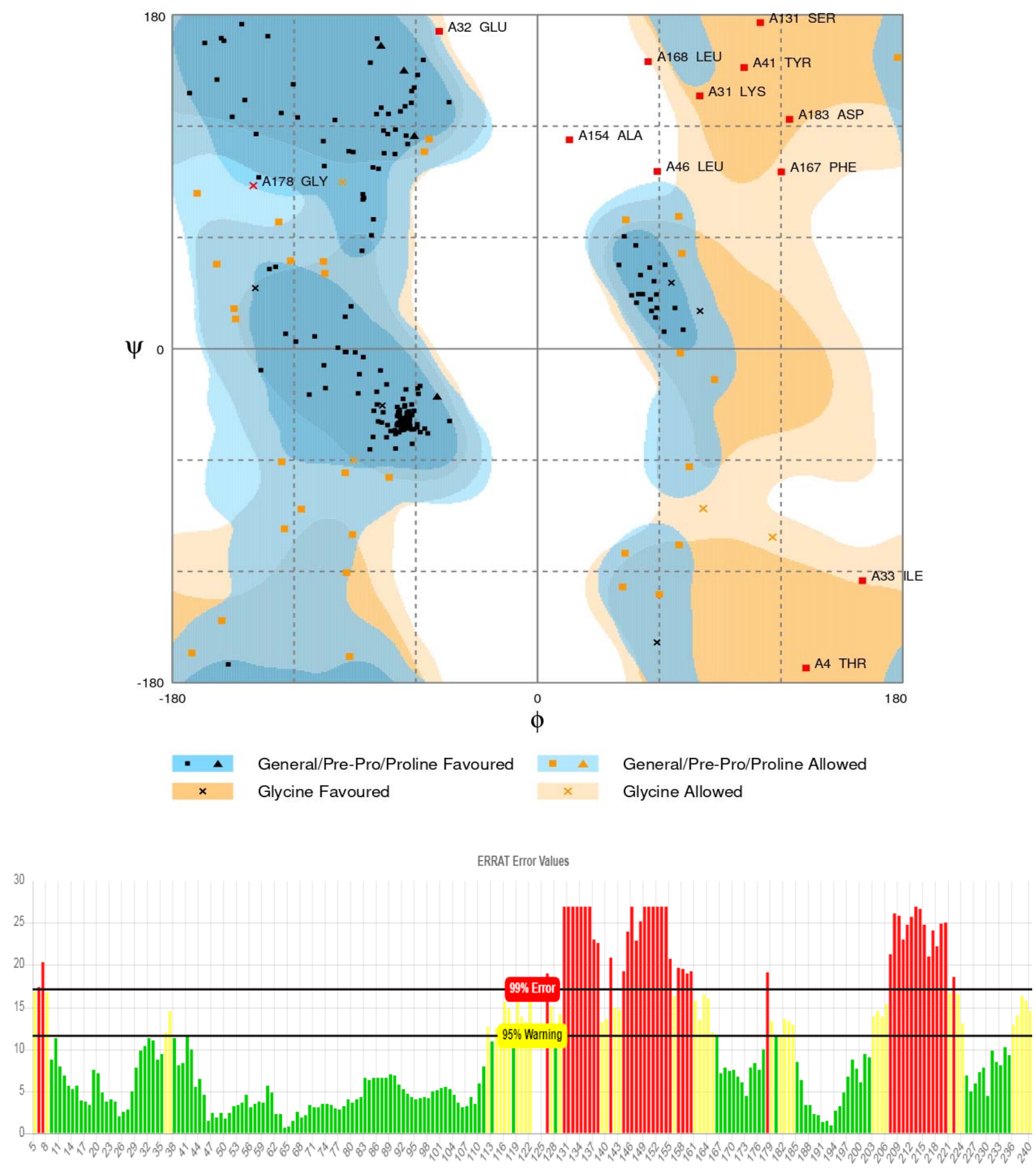

Figure 2. 3D structure, Ramachandhan plot, ERRAT value

\section{Sub-cellular localization}


Sub-cellular localization is an essential feature of a protein. Cellular functions are usually localized in specific enclosed area; so, foretelling the sub-cellular localization of an unknown protein may possibly use to obtain handy information about their function. Therefore, this information is also valuable for drug designing for the target protein (Wang et al., 2005) For determining the sub-cellular localization o Mta protein we used three online based server and all of these three servers suggested that the location of Mta protein is in the cytoplasm.

The identification and characterization of functional sites on proteins have increasingly become an area of interest. On account of the analysis of the active site residues for the binding of ligands provides insight towards the design of inhibitors for the protein. Result of CASTp sever showed that there are 26 active sites (supplementary file 1) of this protein. The volume and area of the best pocket which identified by using CASTp server is volume (SA) is 1553.115 and area $(\mathrm{SA})$ is 374.141 .

\begin{tabular}{|c|c|c|}
\hline CELLO & ngLOC & PSIpred \\
\hline Cytoplasmic & Cytoplasmic & Cytoplasmic \\
\hline
\end{tabular}

Table 2: Subcellular Localization of Mta

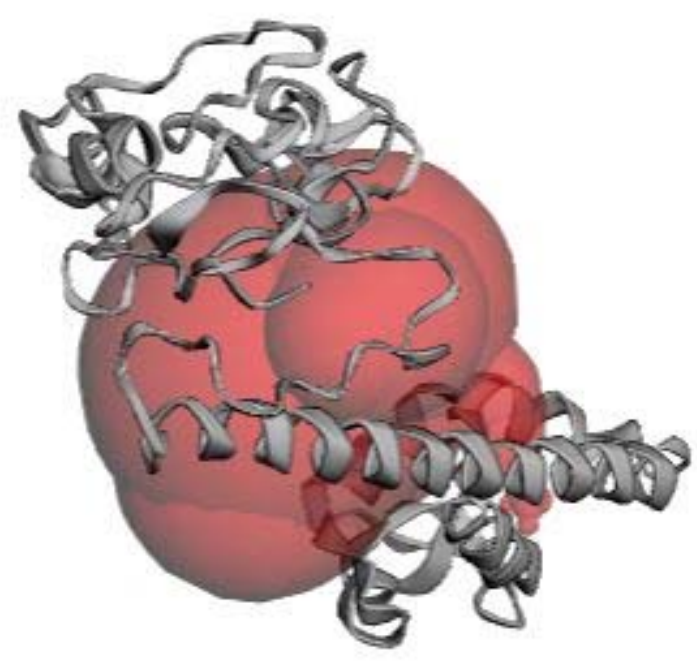

Figure 3. Active site determined by CASTp 


\section{Functional Analysis}

The Conserved Domain Database of NCBI is a resource for the annotation of functional units in proteins which revealed that Mta protein has two domains. These are Helix-Turn-Helix DNA binding domain (HTH_TipAL-Mta) and TipAS antibiotic-recognition domain (TipAS) (Fig. 4). This TipAS domain is found at the C-terminus of some MerR family protein. Based on a collection of hidden Markov models, the SUPERFAMILY 2.0 server showed that Mta protein has two superfamily and two families (Fig. 5). These families are DNA-binding N-terminal domain of transcription activators and Antibiotic binding domain of TipA-like multidrug resistance regulators. Biological sequence motifs are characterized as brief, as a rule, settled length, sequence designs that will speak to vital structural or useful highlights in nucleic acid and protein sequences such as transcription binding sites, splice junctions, active sites, or interaction interfaces. Result of Motif Search tool showed that Mta protein of Bacillus atrophaeus UCMB5137 has five motifs (Fig. 6) (supplementary file 2). STRING visualizes weighted and integrated and a confidence score of protein's functional associations in a network of genome-wide connectivity (Szklarczyk, 2016). The STRING server has detected three interacting proteins viz., ADP34599.1, DnaJ and ADP31438.1, where ADP34599.1 and ADP31438.1 are Transcriptional regulators (Fig. 7). Among them DnaJ protein is a chaperone protein which participates actively within the reaction to hyperosmotic and heat shock through preventing the aggregation of stressdenatured proteins and by disaggregating proteins. 
bioRxiv preprint doi: https://doi.org/10.1101/2020.12.29.424731; this version posted December 30, 2020. The copyright holder for this preprint (which was not certified by peer review) is the author/funder, who has granted bioRxiv a license to display the preprint in perpetuity. It is made available under aCC-BY-NC-ND 4.0 International license.

Conserved domains on [Icl|segsig_MRLTV_d3f5a84ae81d914185d81337ebfc41 e0]

View $\lfloor$ Concise Results v $\mid$ ?

AKL87074.1 Mta [Bacillus atrophaeus UCMB-5137]

\section{Protein Classification}

MerR family transcriptional regulator (domain architecture ID 10099974)

MerR family transcriptional regulator promotes transcription by reconfiguring the spacer between the -35 and -10 promoter elements, similar to TipAL, Mta, and SkgA transcription regulators

\section{Graphical summary $\square$ Zoom to residue level show extra options »}

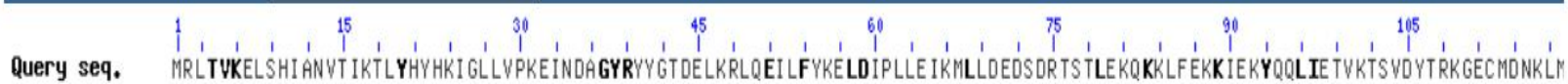

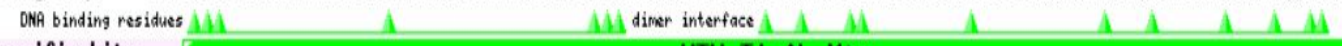

$\begin{array}{lc}\text { Specific hits } & \text { HTH_TipAL-Mta } \\ \text { Superfanilies } & \text { HTH_MerR-SF superfamily }\end{array}$

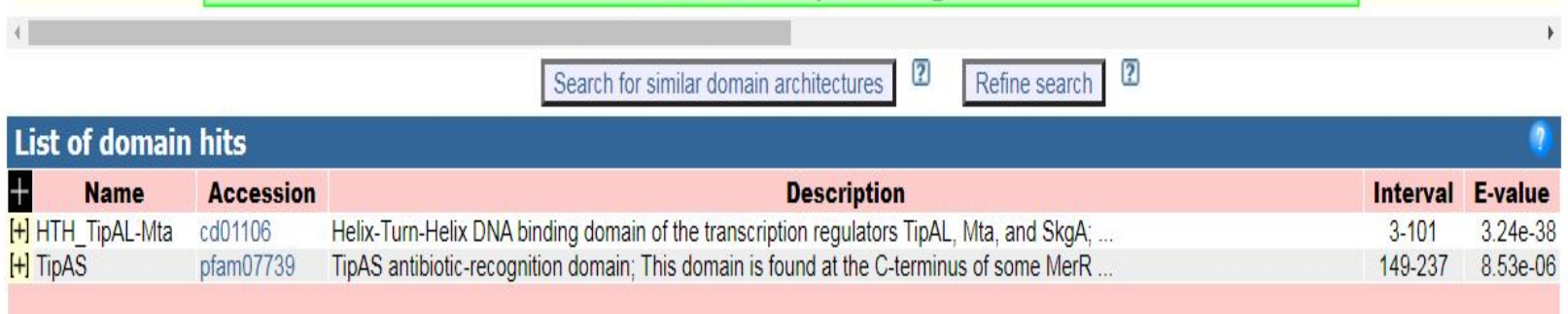

\section{Figure 4: Domain search using NCBI CDD}

AKL87074.1

\begin{tabular}{|c|c|c|c|c|c|c|c|c|c|}
\hline \multirow{2}{*}{$\begin{array}{r}\text { Show } \\
\frac{1}{4}\end{array}$} & \multirow{2}{*}{$\begin{array}{l}50 \quad \vee \\
\text { Sequence }\end{array}$} & \multicolumn{2}{|l|}{ entries } & & \multicolumn{2}{|c|}{ Show weak hits: } & OFF & \multirow[t]{2}{*}{ Search: } & \\
\hline & & $\begin{array}{l}\text { Start } \\
\text { Residue }\end{array}$ & $\begin{array}{l}\text { End } \\
\text { Residue }\end{array}$ & Superfamily & $\begin{array}{l}\text { Superfamily } \\
\text { E-value }\end{array}$ & Family & & & $\begin{array}{l}\text { Family } \\
\text { E-value }\end{array}$ \\
\hline & AKL87074.1 & 3 & 105 & Putative DNA-binding domain & $3.63 e-23$ & \multicolumn{3}{|c|}{$\begin{array}{l}\text { DNA-binding N-terminal domain of } \\
\text { transcription activators }\end{array}$} & 0.00044 \\
\hline 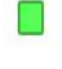 & AKL87074.1 & 161 & 237 & $\begin{array}{l}\text { Antibiotic binding domain of TipA-like } \\
\text { multidrug resistance regulators }\end{array}$ & 0.00000418 & $\begin{array}{l}\text { Antibiotic } \\
\text { multidrug }\end{array}$ & $\begin{array}{l}\text { domain } \\
\text { ce regul }\end{array}$ & $\begin{array}{l}\text { of TipA-like } \\
\text { ators }\end{array}$ & 0.017 \\
\hline
\end{tabular}

Figure 5: Superfamily and Family of Mta protein 


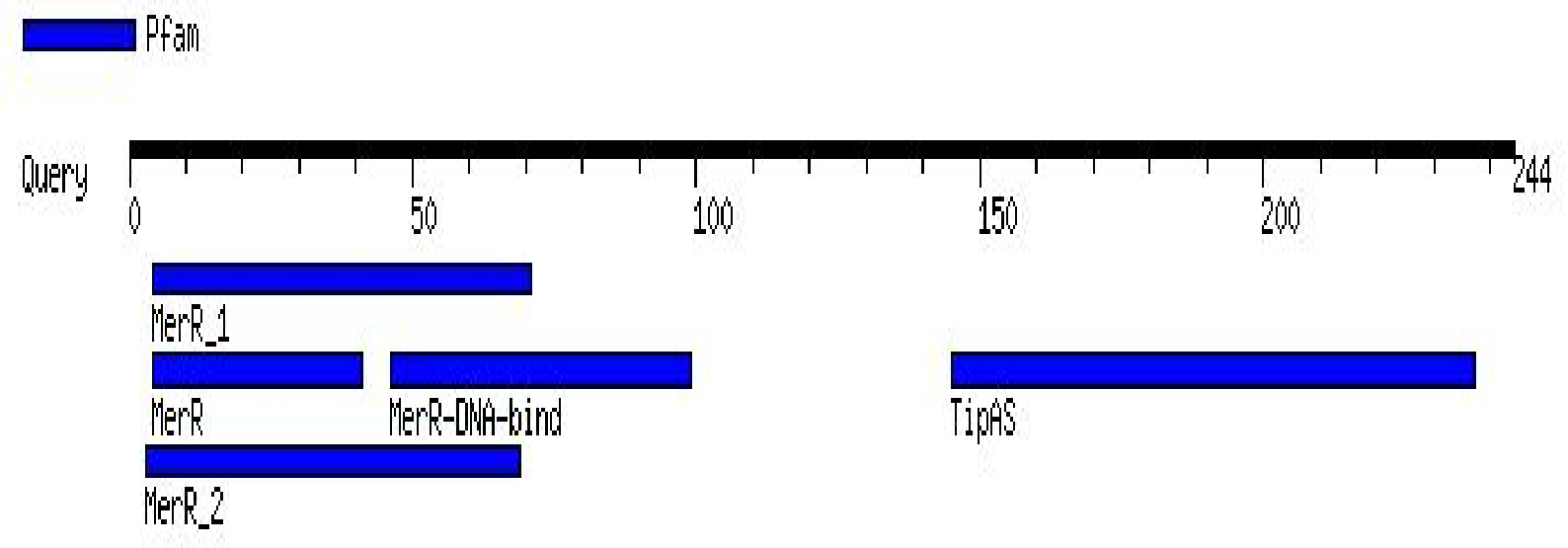

Figure 6: Motifs found using motif finder

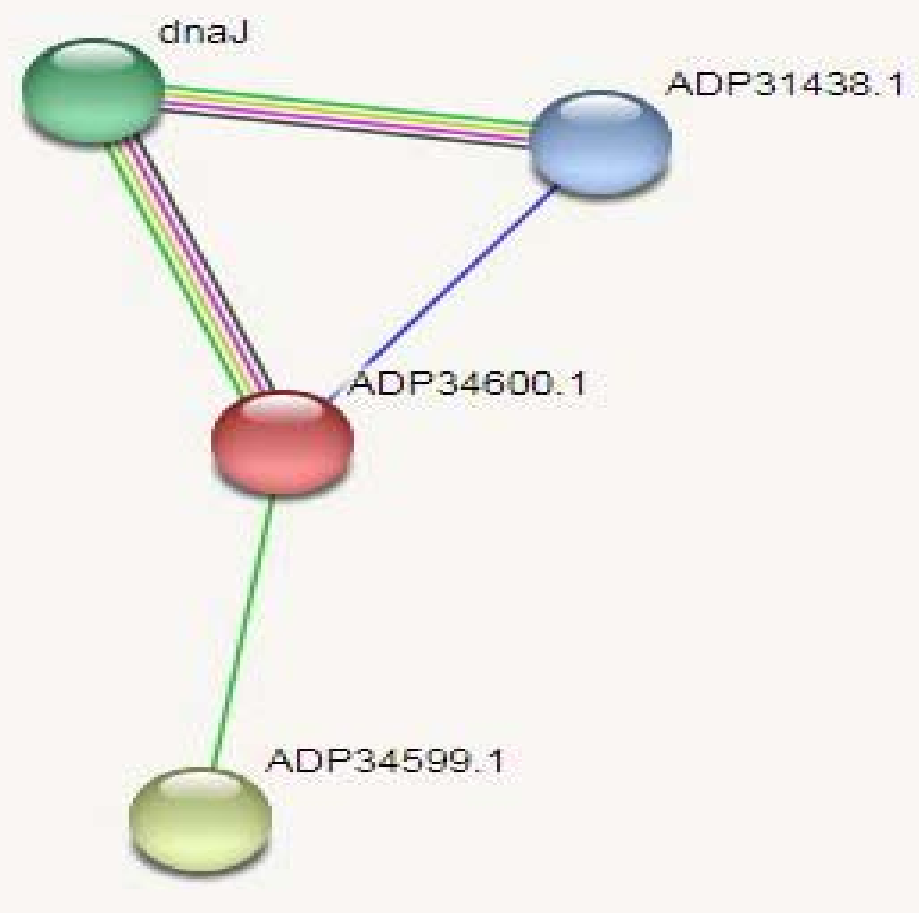

Figure 7. Protein-protein Interaction analysis using STRING

\section{Phylogenetic Analysis}

Phylogenetics is vital since it improves our understanding of how genes, genomes, species (and molecular sequences more generally) evolve. The UPGMA tree was contructed for focused on protein utilizing MEGA software ( 


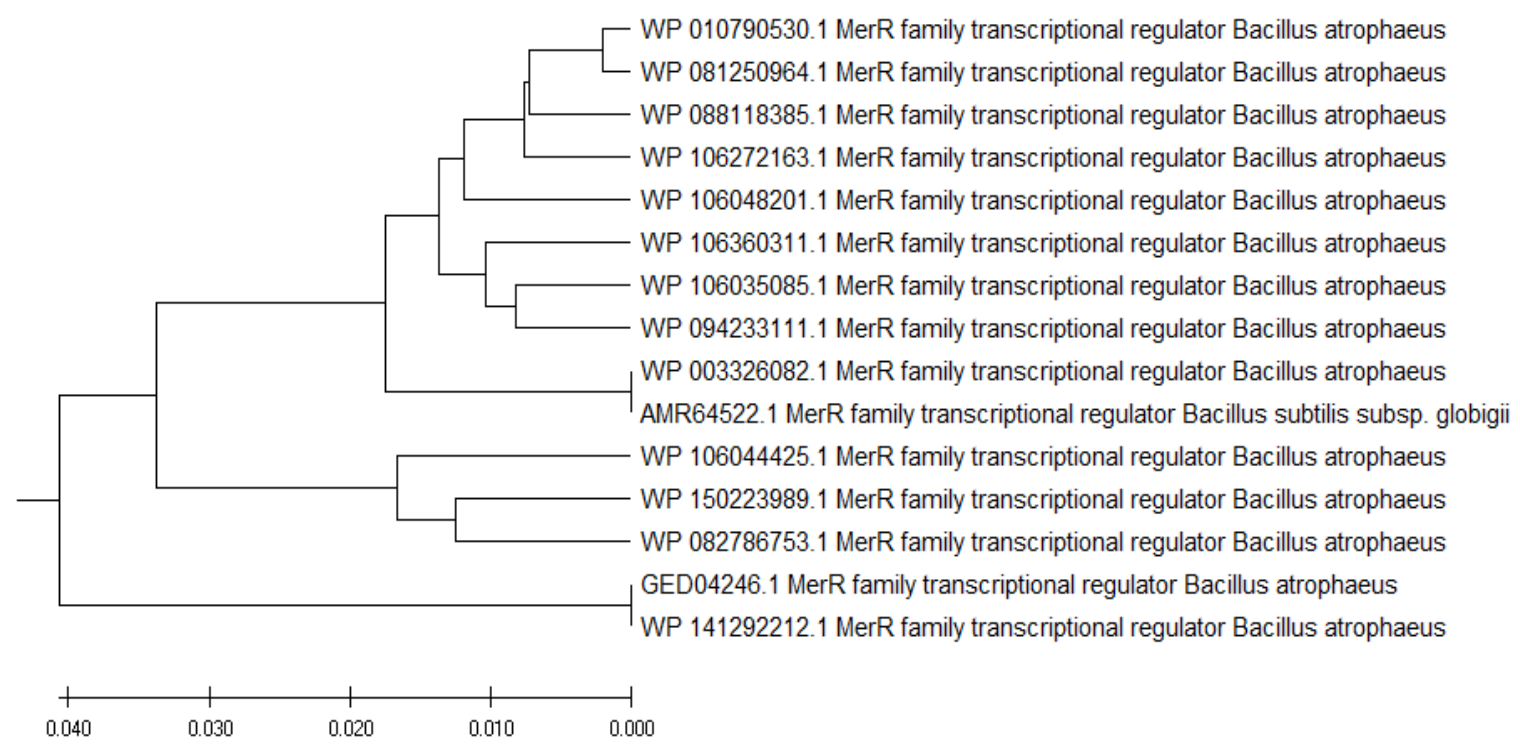

Figure 8: Phylogenetic Analysis using MEGA

The optimal tree with the sum of branch length $=0.22278011$ is shown. The tree is drawn to scale, with branch lengths in the same units as those of the evolutionary distances used to infer the phylogenetic tree. The evolutionary distances were computed using the Poisson correction method and are in the units of the number of amino acid substitutions per site. This analysis involved 15 amino acid sequences. All ambiguous positions were removed for each sequence pair (pairwise deletion option). There were a total of 245 positions in the final dataset.

The present work might be shown some important aspects in future direction in computational studies. Firstly, this study demonstrates about the structural annotation of Mta protein which is now-a-days getting evoking interest to the present reaserachers because of its function in antibiotic resistance mechanism (Musarrat et al., 2009). Secondly, knowing the nature of the protein such as cytosplasmic, thermostable and folded might help to work out wet lab experiments ( $\mathrm{Li}$ et al., 2015) less effortlessly limiting the number of frequent trials and errors etc. Thirdly, the active site of Mta protein and protein interaction analysis gives us an overview on the function of Mta protein. This in silico based information about Mta protein will play an important role in further researcher related antibiotic resistance mechanism. Through utilization of this data researcher can propose some supportive drug during antibiotic treatment by docking analysis to improve efficacy of antibiotic by prohibiting the activation of Mta protein. Activation of Mta protein is responsible for activating multidrug efflux proteins inside the cell. 


\section{Conclusion}

Mta protein, one of the key proteins present in different microorganisms, plays important role in antibiotic resistance mechanism. Therefore, understanding the structural properties of this protein is important to get further insight into the functional aspect and interaction with other proteins and molecules. From the in silico characterization of this study, it was revealed that Mta protein is a thermostable, acidic, and a molecular mass of 28961.95 Da having mainly two conserved domains. This work might be a valuable contribution in the field of Bioinformatics research and may help other researchers to get an idea about the protein structure, its physicochemical properties, structural motifs, and protein protein interaction essential for pharmaceutical and health sector.

\begin{tabular}{|l|l|l|}
\hline Pfam & Independent E-value & Description \\
\hline$\underline{\text { MerR_1 }}$ & $4 . .71(3 \mathrm{e}-12)$ & $\begin{array}{l}\text { PF13411, MerR HTH family } \\
\text { regulatory protein }\end{array}$ \\
\hline$\underline{\text { MerR }}$ & $4 . .41(3.3 \mathrm{e}-11)$ & $\begin{array}{l}\text { PF00376, MerR family } \\
\text { regulatory protein }\end{array}$ \\
\hline$\underline{\text { TipAS }}$ & $145 . .237(1.5 \mathrm{e}-10)$ & $\begin{array}{l}\text { PF07739, TipAS antibiotic- } \\
\text { recognition domain }\end{array}$ \\
\hline$\underline{\text { MerR-DNA-bind }}$ & $46 . .99(0.0002)$ & $\begin{array}{l}\text { PF09278, MerR, DNA } \\
\text { binding }\end{array}$ \\
\hline$\underline{\text { MerR_2 }}$ & $3 . .69(0.1)$ & $\begin{array}{l}\text { PF13591, MerR HTH family } \\
\text { regulatory protein }\end{array}$ \\
\hline
\end{tabular}

Supplementary Table 2: Motifs with Independent E-value

\begin{tabular}{|c|c|c|}
\hline Pocket ID & Area (SA) & Volume (SA) \\
\hline 1 & 374.141 & 1553.115 \\
\hline 2 & 494.368 & 407.104 \\
\hline
\end{tabular}


bioRxiv preprint doi: https://doi.org/10.1101/2020.12.29.424731; this version posted December 30, 2020. The copyright holder for this preprint (which was not certified by peer review) is the author/funder, who has granted bioRxiv a license to display the preprint in perpetuity. It is made available under aCC-BY-NC-ND 4.0 International license.

\begin{tabular}{|c|c|c|}
\hline 3 & 169.632 & 73.266 \\
\hline 4 & 80.306 & 20.749 \\
\hline 5 & 21.781 & 6.768 \\
\hline 6 & 28.810 & 6.515 \\
\hline 7 & 11.698 & 4.145 \\
\hline 8 & 14.951 & 3.757 \\
\hline 9 & 13.712 & 2.221 \\
\hline 10 & 11.145 & 1.755 \\
\hline 11 & 6.359 & 1.436 \\
\hline 12 & 7.012 & 1.397 \\
\hline 13 & 3.082 & 0.848 \\
\hline 14 & 5.136 & 0.562 \\
\hline 15 & 1.781 & 0.439 \\
\hline 16 & 1.709 & 0.072 \\
\hline 17 & 1.541 & 0.071 \\
\hline 18 & 0.816 & 0.039 \\
\hline 19 & 0.624 & 0.022 \\
\hline 20 & 0.764 & 0.019 \\
\hline 21 & 0.744 & 0.011 \\
\hline 22 & 0.336 & 0.007 \\
\hline 23 & 0.251 & 0.007 \\
\hline 24 & 0.385 & 0.007 \\
\hline 25 & 0.018 & 0.000 \\
\hline 26 & 0.002 & 0.000 \\
\hline & $2 . P 0 c k$ & \\
\hline
\end{tabular}

Supplementary Table 2: Pockets with area and volume 


\section{References}

Godsey, M. H., Baranova, N. N., Neyfakh, A. A., \& Brennan, R. G. (2001). Crystal structure of MtaN, a global multidrug transporter gene activator. Journal of Biological Chemistry, 276(50), 47178-47184.

Newberry, K. J., \& Brennan, R. G. (2004). The structural mechanism for transcription activation by MerR family member multidrug transporter activation, $\mathrm{N}$ terminus. Journal of Biological Chemistry, 279(19), 20356-20362.

Brown, N. L., Stoyanov, J. V., Kidd, S. P., \& Hobman, J. L. (2003). The MerR family of transcriptional regulators. FEMS microbiology reviews, 27(2-3), 145-163.

Yang, L., Lu, S., Belardinelli, J., Huc-Claustre, E., Jones, V., Jackson, M., \& Zgurskaya, H. I. (2014). RND transporters protect Corynebacterium glutamicum from antibiotics by assembling the outer membrane. Microbiologyopen, 3(4), 484-496.

Aínsa, J. A., Blokpoel, M. C., Otal, I., Young, D. B., De Smet, K. A., \& Martín, C. (1998). Molecular cloning and characterization of Tap, a putative multidrug efflux pump present in Mycobacterium fortuitum and Mycobacterium tuberculosis. Journal of bacteriology, 180(22), 5836-5843.

Kim, J. Y., Inaoka, T., Hirooka, K., Matsuoka, H., Murata, M., Ohki, R., \& Ochi, K. (2009). Identification and characterization of a novel multidrug resistance operon, mdtRP (yusOP), of Bacillus subtilis. Journal of bacteriology, 191(10), 3273-3281.

Ohki, R., \& Murata, M. (1997). bmr3, a third multidrug transporter gene of Bacillus subtilis. Journal of Bacteriology, 179(4), 1423-1427.

Edgar, R., \& Bibi, E. (1997). MdfA, an Escherichia coli multidrug resistance protein with an extraordinarily broad spectrum of drug recognition. Journal of bacteriology, 179(7), 2274-2280.

Kohler, T., Michea-Hamzehpour, M., Henze, U., Gotoh, N., Curty, L.K., \& Pechere, J.C. (1997) Characterization of MexE-MexF-OprN, a positively regulated multidrug efflux system of Pseudomonas aeruginosa. Molecular microbiology, 23(2), 345-354. 
Lubelski, J., De Jong, A., Van Merkerk, R., Agustiandari, H., Kuipers, O. P., Kok, J., \& Driessen, A. J. (2006). LmrCD is a major multidrug resistance transporter in Lactococcus lactis. Molecular microbiology, 61(3), 771-781.

Van Veen, H. W., Venema, K., Bolhuis, H., Oussenko, I., Kok, J., Poolman, B., \& Konings, W. N. (1996). Multidrug resistance mediated by a bacterial homolog of the human multidrug transporter MDR1. Proceedings of the National Academy of Sciences, 93(20), 10668-10672.

Baranova, N. N., Danchin, A., \& Neyfakh, A. A. (1999). Mta, a global MerR-type regulator of the Bacillus subtilis multidrug-efflux transporters. Molecular microbiology, 31(5), 1549-1559.

Floyd, J. L., Smith, K. P., Kumar, S. H., Floyd, J. T., \& Varela, M. F. (2010). LmrS is a multidrug efflux pump of the major facilitator superfamily from Staphylococcus aureus. Antimicrobial agents and chemotherapy, 54(12), 5406-5412.

Hashimoto, K., Ogawa, W., Nishioka, T., Tsuchiya, T., \& Kuroda, T. (2013). Functionally cloned pdrM from Streptococcus pneumoniae encodes a Na+ coupled multidrug efflux pump. PLoS One, 8(3), e59525.

Boncoeur, E., Durmort, C., Bernay, B., Ebel, C., Di Guilmi, A. M., Croizé, J., \& Jault, J. M. (2012). PatA and PatB form a functional heterodimeric ABC multidrug efflux transporter responsible for the resistance of Streptococcus pneumoniae to fluoroquinolones. Biochemistry, 51(39), 7755-7765.

Kumar, R., Koul, S., Kumar, P., \& Kalia, V. C. (2016). Searching biomarkers in the sequenced genomes of Staphylococcus for their rapid identification. Indian journal of microbiology, 56(1), 64-71.

Karumuri, S., Singh, P. K., \& Shukla, P. (2015). In silico analog design for terbinafine against Trichophyton rubrum: a preliminary study. Indian journal of microbiology, 55(3), 333-340.

Kalia, V. C., \& Kumar, P. (2015). Genome wide search for biomarkers to diagnose Yersinia infections. Indian journal of microbiology, 55(4), 366-374.

Verma, A., Singh, V. K., \& Gaur, S. (2016). Computational based functional analysis of Bacillus phytases. Computational biology and chemistry, 60, 53-58. 
Pramanik, K., Soren, T., Mitra, S., \& Maiti, T. K. (2017). In silico structural and functional analysis of Mesorhizobium ACC deaminase. Computational Biology and Chemistry, 68, 12-21.

Nakamura, L. K. (1989). Taxonomic Relationship of Black-Pigmented Bacillus subtilis Strains and a Proposal for Bacillus atrophaeus sp. nov. International Journal of Systematic and Evolutionary Microbiology, 39(3), 295-300.

Van Veen, H. W., Putman, M., Margolles, A., Sakamoto, K., \& Konings, W. N. (1999). Structure-function analysis of multidrug transporters in Lactococcus lactis. Biochimica et Biophysica Acta (BBA)-Biomembranes, 1461(2), 201-206.

Neu, H. C. (1992). The crisis in antibiotic resistance. Science, 257(5073), 1064-1073.

Moellering Jr, R. C. (1998). Introduction: problems with antimicrobial resistance in grampositive cocci. Reviews of Infectious Diseases, 26(5), 1177-1178.

Gasteiger, E., Hoogland, C., Gattiker, A., Wilkins, M.R., Appel, R.D. and Bairoch, A., 2005. Protein identification and analysis tools on the ExPASy server. In The proteomics protocols handbook (pp. 571-607). Humana press.

Liam J. McGuffin, Kevin Bryson, David T. Jones , April 2000 Bioinformatics, Volume 16, Issue, Pages 404-405

Kumar, T. A. (2013). CFSSP: Chou and Fasman secondary structure prediction server. Wide Spectrum, 1(9), 15-19.

Yang, J., Yan, R., Roy, A., Xu, D., Poisson, J., \& Zhang, Y. (2015). The I-TASSER Suite: protein structure and function prediction. Nature methods, 12(1), 7-8.

Ko, J., Park, H., Heo, L., \& Seok, C. (2012). GalaxyWEB server for protein structure prediction and refinement. Nucleic acids research, 40(W1), W294-W297.

Lovell, S. C., Davis, I. W., Arendall III, W. B., De Bakker, P. I., Word, J. M., Prisant, M. G., ... \& Richardson, D. C. (2003). Structure validation by $\mathrm{C} \alpha$ geometry: $\square, \psi$ and C $\beta$ deviation. Proteins: Structure, Function, and Bioinformatics, 50(3), 437-450. 
Yu, C. S., Lin, C. J., \& Hwang, J. K. (2004). Predicting subcellular localization of proteins for Gram-negative bacteria by support vector machines based on n-peptide compositions. Protein science, 13(5), 1402-1406.

King, B. R., \& Guda, C. (2007). ngLOC: an n-gram-based Bayesian method for estimating the subcellular proteomes of eukaryotes. Genome biology, 8(5), R68.

Buchan, D. W., \& Jones, D. T. (2019). The PSIPRED protein analysis workbench: 20 years on. Nucleic acids research, 47(W1), W402-W407.

Tian, W., Chen, C., Lei, X., Zhao, J., \& Liang, J. (2018). CASTp 3.0: computed atlas of surface topography of proteins. Nucleic acids research, 46(W1), W363-W367.

Marchler-Bauer, A., Derbyshire, M. K., Gonzales, N. R., Lu, S., Chitsaz, F., Geer, L. Y., ... \& Lanczycki, C. J. (2015). CDD: NCBI's conserved domain database. Nucleic acids research, 43(D1), D222-D226.

Colovos, C., \& Yeates, T. O. (1993). Verification of protein structures: patterns of nonbonded atomic interactions. Protein science, 2(9), 1511-1519.

Szklarczyk, D., Gable, A. L., Lyon, D., Junge, A., Wyder, S., Huerta-Cepas, J., ... \& Jensen, L. J. (2019). STRING v11: protein-protein association networks with increased coverage, supporting functional discovery in genome-wide experimental datasets. Nucleic acids research, 47(D1), D607-D613.

Gough, J., Karplus, K., Hughey, R. and Chothia, C., 2001. Assignment of homology to genome sequences using a library of hidden Markov models that represent all proteins of known structure. Journal of molecular biology, 313(4), pp.903-919.

Kanehisa, M., Goto, S., Kawashima, S. and Nakaya, A., 2002. The KEGG databases at GenomeNet. Nucleic acids research, 30(1), pp.42-46.

Kumar, S., Stecher, G., Li, M., Knyaz, C. and Tamura, K., 2018. MEGA X: molecular evolutionary genetics analysis across computing platforms. Molecular biology and evolution, 35(6), pp.1547-1549. 
Musarrat, J., Al Khedhairy, A. A., Al-Arifi, S., \& Khan, M. S. (2009). Role of 1Aminocyclopropane-1-carboxylate deaminase in Rhizobium-Legume Symbiosis. In Microbial Strategies for Crop Improvement (pp. 63-83). Springer, Berlin, Heidelberg.

Li, Z., Chang, S., Ye, S., Chen, M., Lin, L., Li, Y., \& An, Q. (2015). Differentiation of 1aminocyclopropane-1-carboxylate (ACC) deaminase from its homologs is the key for identifying bacteria containing ACC deaminase. FEMS Microbiology Ecology, 91(10), fiv112.

Szklarczyk, D., Morris, J. H., Cook, H., Kuhn, M., Wyder, S., Simonovic, M., \& Jensen, L. J. (2016). The STRING database in 2017: quality-controlled protein-protein association networks, made broadly accessible. Nucleic acids research, gkw937.

Roy, S., Banerjee, V., \& Das, K. P. (2015). Understanding the physical and molecular basis of stability of arabidopsis DNA Pol $\lambda$ under UV-B and high $\mathrm{NaCl}$ stress. Plos one, 10(7), e0133843. Verma, A., Singh, V. K., \& Gaur, S. (2016). Computational based functional analysis of Bacillus phytases. Computational biology and chemistry, 60, 53-58.

Pramanik, K., Soren, T., Mitra, S., \& Maiti, T. K. (2017). In silico structural and functional analysis of Mesorhizobium ACC deaminase. Computational Biology and Chemistry, 68, 12-21. Wang, J., Sung, W. K., Krishnan, A., \& Li, K. B. (2005). Protein subcellular localization prediction for Gram-negative bacteria using amino acid subalphabets and a combination of multiple support vector machines. BMC bioinformatics, 6(1), 174. 